\title{
Synthesis and Antifungal Study of Some Acetophenone Oximes and Their Terphthaloyl Oxime Esters
}

\author{
Ramadan Ali Bawa \\ Department of Chemistry, Faculty of Science, Misurata University, P O Box 2478, Misurata, Libya \\ Mona Mohammed Friwan \\ Department of Chemistry, Faculty of Science, Misurata University, P O Box 2478, Misurata, Libya
}

\begin{abstract}
Acetophenone oximes $1-5$ along with their terphthaloyl oxime esters $6-10$ have been synthesized in moderate to good yields. Only one oxime was formed in as E/Z two isomers in a ratio of (8:1). These resulting oxime derivatives were involved in an antifungal screening against the Aspergillus niger at concentration of $30 \mathrm{ppm}$. Two commercially available antifungal agents, clorotimazole and daktarin, were employed as references at the same concentration, $30 \mathrm{ppm}$. The antifungal results for the oxime derivatives $1-10$ showed inhibitory levels ranging from $38 \%$ to $100 \%$, whereas the antifungal potentials for the two references were found to be $\sim 63 \%$ and $68 \%$ for clorotimazole and daktarin respectively.
\end{abstract}

Keywords: Acetophenone; Oximes; Terphthaloyl esters; Synthesized; Antifungal; Inhibitory levels.

\section{BY: Creative Commons Attribution License 4.0}

\section{Introduction}

Oximes are found in many bioactive molecules. These molecules have a wide range of activities, including antibacterial, antifungal, anti-inflammatory, antioxidant, anti-diabetes and cytotoxic activities as well as their use as precursors in the synthesis of photosensitive materials [1,2]. Oxime esters could be obtained by the reaction of ketoor aldoximes with acid chlorides or acid anhydrides. Oxime esters are important molecules for the synthesis of biologically active heterocyclic compounds [3]. Oxime esters have also been used to cleavage DNA [4-6], herbicidal and antitumor activities [7,8]. Unsymmetrical dioxime esters such as $(2 E, 4 E)$-(4-imino $O$-benzoyl-2-imino $O$ terphthaloyl)pentane, $(2 E, 4 E)$-(4-imino $O$-benzoyl-2-imino $O$-tosyl)pentane and $(2 E, 4 E$ )-(4-imino $O$-terphthaloyl-2imino $O$-tosyl)pentane have been synthesized and characterized [9]. A number of substituted 1-methyl-2,6diarylpiperidin-4-one $O$-benzyl oximes have been synthesized and their antimicrobial activities. One compound out of thirty synthesized oxime derivatives showed very good activity than the standard drug against aspergillus niger [10].

\section{Materials and Methods}

\subsection{Materials}

Acetophenone, 4-methylacetophenone, 4-hydroxyacetophenone, 4-aminoacetophenone, hydroxylamine hydrochloride, terphthaloyl chloride, potassium carbonate, anhydrous sodium sulphate, triethyl amine and chloroform. These chemicals were used without further purification.

\subsection{Instrumentation}

Melting points were measured on a Barnstead electrothermal IA 9100. ${ }^{1} \mathrm{HNMR}$ spectrum was recorded on a JEOL ECA-500 II spectrometer. Residual proton signal from the deuteriated solvent was used as reference [DMSO $\left({ }^{1} \mathrm{H}, 2.50 \mathrm{ppm}\right)$, whereas coupling constants were measured in hertz $\left.(\mathrm{Hz})\right]$. Infrared spectrum was recorded on Jasco FT/IR-4100 Fourier transform infrared spectrometer. Mass spectrum was recorded on a Shimadzu Qp-2010 Plus. Antifungal study was conducted using petri dishes $9.0 \mathrm{~cm}$.

\subsection{General Procedures for The Synthesis of acetophenone oximes 1 - 5:}<smiles>C/C(=N\O)c1ccccc1</smiles>

major isomer $(88.2 \%)$<smiles>C/C(=N/O)c1ccccc1</smiles>

minor isomer $(\mathbf{1 1 . 8 \% )}$

A literature procedure [1] was adapted towards the synthesis of the desired oxime. Solution of hydroxylamine hydrochloride $\left(1.08 \mathrm{mmol}\right.$ in $10 \mathrm{~cm}^{3}$ of distilled water) and a solution of potassium hydroxide $\left(0.80 \mathrm{mmol}\right.$ in $5 \mathrm{~cm}^{3}$ of distilled water) were placed in a round-bottomed flask and stirred at room temperature. Acetophenone (1 mmol) 
was then added while stirring and the reaction mixture was refluxed. At the start of boiling, small amounts of ethanol $\left(5 \mathrm{~cm}^{3}\right)$ were added from time to time to reaction mixture through the condenser until the boiling solution becomes clear. The reaction was left under reflux for further an hour after which the reaction vessel was allowed to cool gradually to room temperature. The $\mathrm{pH}$ of the reaction mixture was measured and found as expected to be acidic. A solution of $1 \mathrm{~N} \mathrm{KOH}$ was added to the reaction mixture until the solution became neutral. The reaction mixture was then refluxed for further $30 \mathrm{~min}$, cooled to room temperature. The $\mathrm{pH}$ was measured and found to be still acidic. Addition of $1 \mathrm{~N} \mathrm{KOH}$ solution was required and the reaction mixture was refluxed for another $10 \mathrm{~min}, \mathrm{cooled}, \mathrm{pH}$ was measured and found to be neutral. The reaction mixture was transferred into a beaker containing ice-water (100 $\left.\mathrm{cm}^{3}\right)$, the acetophenone oxime derivative was precipitated rapidly, filtered, washed with cold water $\left(3 \times 10 \mathrm{~cm}^{3}\right)$ and air dried to give the desired compound. The product was recrystallized from diethyl ether.

Acetophenone Oxime 1: white powder, (2.80 gm, $20.74 \mathrm{mmol}, 31 \%$ yield); mp $67^{\circ} \mathrm{C}$ (lit. $55-60{ }^{\circ} \mathrm{C}$, Aldrich); IR $v_{\max }\left(\mathrm{cm}^{-1}\right) 3212(\mathrm{OH}), 1497(\mathrm{C}=\mathrm{N})$. Major isomer $(88.2 \%):{ }^{1} \mathrm{HNMR}(\mathrm{DMSO}-\mathrm{d} 6,500 \mathrm{MHz}) \delta 11.24(1 \mathrm{H}, \mathrm{s}$, $\mathrm{OH}), 7.65(2 \mathrm{H}, \mathrm{d}, J$ 7.7, $2 \times \mathrm{Ar}-\mathrm{CH}), 7.38-7.32(3 \mathrm{H}, \mathrm{m}, 3 \times \mathrm{Ar}-\mathrm{CH}), 2.15\left(3 \mathrm{H}, \mathrm{s}, \mathrm{CH}_{3}\right)$; Minor isomer $(11.8 \%)$ : ${ }^{1} \mathrm{HNMR}$ (DMSO-d6, $\left.500 \mathrm{MHz}\right) \delta 11.23(1 \mathrm{H}, \mathrm{s}, \mathrm{OH}), 7.94(2 \mathrm{H}, \mathrm{d}, J$ 7.9, $2 \times \mathrm{Ar}-\mathrm{CH}), 7.52-7.49(3 \mathrm{H}, \mathrm{m}, 3 \times \mathrm{Ar}-$ $\mathrm{CH}), 2.56$ (3 H, s, $\left.\mathrm{CH}_{3}\right)$. Mass spec m/z ( $\mathrm{C}_{8} \mathrm{H}_{9} \mathrm{NO}$, MWt 135.15) 135 (75\%), $118(22 \%), 106(40 \%), 94(42 \%), 77$ $(100 \%)$.

4-Methyl acetophenone oxime 2: white powder (4.50 gm, $30.16 \mathrm{mmol}, 51 \%$ yield); $\mathrm{mp} 93{ }^{\circ} \mathrm{C}$; IR $v_{\max }\left(\mathrm{cm}^{-1}\right)$ $3212(\mathrm{OH}), 1513(\mathrm{C}=\mathrm{N}) .{ }^{1} \mathrm{HNMR}(\mathrm{DMSO}-\mathrm{d} 6,500 \mathrm{MHz}) \delta 11.08(1 \mathrm{H}, \mathrm{s}, \mathrm{OH}), 7.52(2 \mathrm{H}, \mathrm{d}, \mathrm{J} 7.5,2 \times \mathrm{Ar}-\mathrm{CH}), 7.17$ $(2 \mathrm{H}, \mathrm{d}, J$ 7.2, $2 \times \mathrm{Ar}-\mathrm{CH}), 2.29\left(3 \mathrm{H}, \mathrm{s}, \mathrm{CH}_{3}\right), 2.11\left(3 \mathrm{H}, \mathrm{s}, \mathrm{CH}_{3}\right)$. Mass spec m/z $\left(\mathrm{C}_{9} \mathrm{H}_{11} \mathrm{NO}, \mathrm{MWt} 149.19\right) 149$ (90\%), 132 (20\%), $117(23 \%), 107$ (22\%), 94 (100\%), $65(53 \%)$.

4-Hydroxy acetophenone oxime 3: white powder (4.10 gm, $27.12 \mathrm{mmol}, 46 \%$ yield); mp $140{ }^{\circ} \mathrm{C}$ (lit. $142-144$ ${ }^{\circ} \mathrm{C}$, Aldrich); IR $v_{\max }\left(\mathrm{cm}^{-1}\right) 3267(2 \times \mathrm{OH}), 1640(\mathrm{C}=\mathrm{N}) .{ }^{1} \mathrm{HNMR}$ (DMSO-d6, $\left.500 \mathrm{MHz}\right) \delta 10.86(1 \mathrm{H}, \mathrm{s}, \mathrm{OH}$, oxime), 9.67 (1 H, s, OH, phenolic), $7.45(2 \mathrm{H}, \mathrm{d}, J$ 7.5, $2 \times \mathrm{Ar}-\mathrm{CH}), 6.75(2 \mathrm{H}, \mathrm{d}, J$ 6.8, $2 \times \mathrm{Ar}-\mathrm{CH}), 2.07$ (3 H, s, $\mathrm{CH}_{3}$ ). Mass spec m/z $\left(\mathrm{C}_{8} \mathrm{H}_{9} \mathrm{NO}_{2}\right.$, MWt 151.16) 151 (100\%), 134 (40\%), 119 (30\%), $110(15 \%), 94(60 \%), 65(80 \%)$.

4-Amino acetophenone oxime 4: deep brown solid (5.0 gm, $33.29 \mathrm{mmol}, 56 \%$ yield); mp $150{ }^{\circ} \mathrm{C}\left(\right.$ lit. $153{ }^{\circ} \mathrm{C}$, chemical book website); IR $v_{\max }\left(\mathrm{cm}^{-1}\right) 3352(\mathrm{OH}), 3289$ and $3162\left(\mathrm{NH}_{2}\right), 1632(\mathrm{C}=\mathrm{N}) .{ }^{1} \mathrm{HNMR}(\mathrm{DMSO}-\mathrm{d} 6,500$ $\mathrm{MHz}) \delta 7.32(2 \mathrm{H}, \mathrm{d}, J 7.3,2 \times \mathrm{Ar}-\mathrm{CH}), 6.53(2 \mathrm{H}, \mathrm{d}, J 6.5,2 \times \mathrm{Ar}-\mathrm{CH}), 5.32\left(2 \mathrm{H}, \mathrm{br}\right.$ s, $\left.\mathrm{NH}_{2}\right), 2.02\left(3 \mathrm{H}, \mathrm{s}, \mathrm{CH}_{3}\right)$. Mass spec m/z $\left(\mathrm{C}_{8} \mathrm{H}_{10} \mathrm{~N}_{2} \mathrm{O}\right.$, MWt 150.18) 150 (100\%), 133 (50\%), 118 (35\%), 93 (40\%), 65 (60\%).

4-Nitro acetophenone oxime 5: yellow solid (7.20 gm, $39.97 \mathrm{mmol}, 83 \%$ yield); mp $172{ }^{\circ} \mathrm{C}$ (lit. $\left.169-171{ }^{\circ} \mathrm{C}\right)$ [11]; IR $v_{\max }\left(\mathrm{cm}^{-1}\right) 3220(\mathrm{OH}), 1601(\mathrm{C}=\mathrm{N}), 1511$ and $1337\left(\mathrm{NO}_{2}\right) .{ }^{1} \mathrm{HNMR}(\mathrm{DMSO}-\mathrm{d} 6,500 \mathrm{MHz}) \delta 11.79(1 \mathrm{H}, \mathrm{s}$, $\mathrm{OH}), 8.22(2 \mathrm{H}, \mathrm{d}, J$ 8.21, $2 \times \mathrm{Ar}-\mathrm{CH}), 7.90(2 \mathrm{H}, \mathrm{d}, J$ 7.89, $2 \times \mathrm{Ar}-\mathrm{CH}), 2.19\left(3 \mathrm{H}, \mathrm{s}, \mathrm{CH}_{3}\right) . \mathrm{Mass} \mathrm{spec} \mathrm{m} / \mathrm{z}$ $\left(\mathrm{C}_{8} \mathrm{H}_{8} \mathrm{~N}_{2} \mathrm{O}_{3}\right.$, MWt 180.16) 180 (100\%), 163 (20\%), 133 (22\%), 117 (40\%), 102 (23\%), 89 (38\%), 76 (60\%), 65 $(40 \%)$.

\subsection{General Procedure for the Synthesis of the Terphthaloyl Esters 6 - 10}

An adapted literature procedure [1] was followed to synthesis title compound. The acetophenone oxime derivative $(0.022 \mathrm{mmol})$ in chloroform $\left(40 \mathrm{~cm}^{3}\right)$ in the presence of triethyl amine $(1.30 \mathrm{mmol})$ were placed in a round-bottomed flask and stirred at $0-5{ }^{\circ} \mathrm{C}$. A solution of terphthaloyl chloride $(0.01 \mathrm{mmol})$ in chloroform $\left(50 \mathrm{~cm}^{3}\right)$ was then added dropwise over $30 \mathrm{~min}$. The reaction mixture was left stirring at room temperature for 2 hours, after which distilled water $\left(30 \mathrm{~cm}^{3}\right)$ was added to the mixture and stirred for further $10 \mathrm{~min}$. The organic layer was extracted, dried over anhydrous $\mathrm{Na}_{2} \mathrm{SO}_{4}$ and filtered. The solvent was evaporated in vacuo to obtain the desired oxime ester. The product was recrystallized from diethyl ether.

1-Phenylethan-1-one $O$-[4-(-1-phenylethylideneamino) oxycarbonyl benzoyl oxime 6: off-white solid (4.03 g, $10.08 \mathrm{mmol}, 46 \%)$; mp $183{ }^{\circ} \mathrm{C}$; IR $v_{\max }\left(\mathrm{cm}^{-1}\right) 1710(\mathrm{C}=\mathrm{O}$, ester $), 1683(\mathrm{C}=\mathrm{O}$, ester $), 1429(\mathrm{C}=\mathrm{N})$ and $1408(\mathrm{C}=\mathrm{N})$. ${ }^{1} \mathrm{HNMR}$ (DMSO-d6, $\left.400 \mathrm{MHz}\right) \delta 8.22-8.17(2 \mathrm{H}, \mathrm{m}, 2 \times \mathrm{Ar}-\mathrm{CH}), 8.15-8.11(2 \mathrm{H}, \mathrm{m}, 2 \times \mathrm{Ar}-\mathrm{CH}), 8.10-8.03(8 \mathrm{H}$, $\mathrm{m}, 8 \times \mathrm{Ar}-\mathrm{CH}), 7.85-8.83(1 \mathrm{H}, \mathrm{m}, \mathrm{Ar}-\mathrm{CH}), 7.55-7.50(1 \mathrm{H}, \mathrm{m}, \mathrm{Ar}-\mathrm{CH}), 1.33\left(6 \mathrm{H}, \mathrm{s}, 2 \times \mathrm{CH}_{3}\right)$.

$o, o^{\prime}$-Terephthaloyl bis-1-(p-tolyl)-1-(p-tolyl)ethan-1-one oxime 7: pale brown solid $(3.20 \mathrm{~g}, 7.48 \mathrm{mmol}, 34 \%)$; $\operatorname{mp} 186{ }^{\circ} \mathrm{C}$; IR $v_{\max }\left(\mathrm{cm}^{-1}\right) 1735(\mathrm{C}=\mathrm{O}$, ester $), 1678(\mathrm{C}=\mathrm{O}$, ester $), 1605(\mathrm{C}=\mathrm{N}), 1574(\mathrm{C}=\mathrm{N}) .{ }^{1} \mathrm{HNMR}$ (DMSO-d6, $400 \mathrm{MHz}) \delta 7.89(2 \mathrm{H}, \mathrm{d}, J 7.9,2 \times \mathrm{Ar}-\mathrm{CH}), 7.82(4 \mathrm{H}, \mathrm{d}, J 7.8,4 \times \mathrm{Ar}-\mathrm{CH}), 7.70(4 \mathrm{H}, \mathrm{d}, J 7.7,4 \times \mathrm{Ar}-\mathrm{CH}), 7.57$ $(2 \mathrm{H}, \mathrm{d}, J$ 7.6, $2 \times \mathrm{Ar}-\mathrm{CH}), 2.51\left(6 \mathrm{H}, \mathrm{s}, 2 \times \mathrm{Ar}-\mathrm{CH}_{3}\right), 2.34\left(6 \mathrm{H}, \mathrm{s}, 2 \times \mathrm{CH}_{3}\right)$. Mass spec m/z $\left(\mathrm{C}_{26} \mathrm{H}_{24} \mathrm{~N}_{2} \mathrm{O}_{4}, \mathrm{MWt}\right.$ 428.17) 428 (40\%), 386 (99\%), 344 (20\%), 280 (95\%), 255 (18\%), 149 (100\%), 91 (60\%), 65 (70\%).

$o, o^{\prime}$-Terephthaloyl bis-1-(4-hydroxyphenyl)-1-(4-hydroxyphenyl) ethan-1-one oxime 8: white solid (3.20 g, 7.41 mmol, 32\%); mp $147^{\circ} \mathrm{C}$; IR $v_{\max }\left(\mathrm{cm}^{-1}\right) 3410(2 \times \mathrm{OH}$, ester $), 1730(2 \times \mathrm{C}=\mathrm{O}$, ester $), 1596(2 \times \mathrm{C}=\mathrm{N}) .{ }^{1} \mathrm{HNMR}$ $(\mathrm{DMSO}-\mathrm{d} 6,400 \mathrm{MHz}) \delta 8.23(2 \mathrm{H}, \mathrm{s}, 2 \times \mathrm{Ar}-\mathrm{OH}), 8.16(1 \mathrm{H}, \mathrm{d}, J 8.2, \mathrm{Ar}-\mathrm{CH}), 8.10(1 \mathrm{H}, \mathrm{d}, J 8.1, \mathrm{Ar}-\mathrm{CH}), 7.81(2 \mathrm{H}$, $\mathrm{d}, J$ 7.8, $2 \times \mathrm{Ar}-\mathrm{CH}), 7.45(2 \mathrm{H}, \mathrm{d}, J 7.5,2 \times \mathrm{Ar}-\mathrm{CH}), 7.26-7.06(2 \mathrm{H}, \mathrm{m}, 2 \times \mathrm{Ar}-\mathrm{CH}), 6.84(2 \mathrm{H}, \mathrm{d}, J 6.8,2 \times \mathrm{Ar}-$ $\mathrm{CH}), 6.75(2 \mathrm{H}, \mathrm{d}, J 6.8,2 \times \mathrm{Ar}-\mathrm{CH}), 2.46\left(6 \mathrm{H}, \mathrm{s}, 2 \times \mathrm{CH}_{3}\right)$. Mass spec m/z $\left(\mathrm{C}_{24} \mathrm{H}_{20} \mathrm{~N}_{2} \mathrm{O}_{6}, \mathrm{MWt} 432.13\right) 432(15 \%)$, 417 (5\%), 390 (12\%), 348 (15\%), 299 (22\%), 257 (100\%), 149 (50\%), 109 (40\%), 65 (40\%).

$o, o^{\prime}$-Terephthaloyl bis-1-(4-aminophenyl)-1-(4-aminophenyl) ethan-1-one oxime 9: deep green solid (5.40 g, $12.09 \mathrm{mmol}, 57 \%)$; mp $185{ }^{\circ} \mathrm{C}$; IR $v_{\max }\left(\mathrm{cm}^{-1}\right) 3358\left(2 \times \mathrm{NH}_{2}\right.$, ester $), 1743(2 \times \mathrm{C}=\mathrm{O}$, ester $), 1651(2 \times \mathrm{C}=\mathrm{N})$. ${ }^{1} \mathrm{HNMR}$ (DMSO-d6, $\left.400 \mathrm{MHz}\right) \delta 7.65(2 \mathrm{H}, \mathrm{d}, J 7.7,2 \times \mathrm{Ar}-\mathrm{CH}), 7.48(4 \mathrm{H}, \mathrm{d}, J 7.5,4 \times \mathrm{Ar}-\mathrm{CH}), 7.25(2 \mathrm{H}, \mathrm{d}, J 7.3$, $2 \times \mathrm{Ar}-\mathrm{CH}), 6.86(4 \mathrm{H}, \mathrm{d}, J 6.9,4 \times \mathrm{Ar}-\mathrm{CH}), 3.41\left(4 \mathrm{H}, \mathrm{br} \mathrm{s}, 2 \times \mathrm{NH}_{2}\right), 2.07\left(6 \mathrm{H}, \mathrm{s}, 2 \times \mathrm{CH}_{3}\right) . \mathrm{Mass} \mathrm{spec} \mathrm{m} / \mathrm{z}$ $\left(\mathrm{C}_{24} \mathrm{H}_{22} \mathrm{~N}_{4} \mathrm{O}_{4}\right.$, MWt 430.16) 430 (8\%), 397 (20\%), 324 (20\%), 298 (60\%), 256 (20\%), 192 (20\%), $175(22 \%), 149$ (60\%), 108 (100\%), 65 (98\%). 
$o, o^{\prime}$-Terephthaloyl bis-1-(4-nitrophenyl)-1-(4-nitrophenyl) ethan-1-one oxime 10: yellow solid (4.0 g, 8.16 mmol, 37\%); mp $177^{\circ} \mathrm{C}$; IR $v_{\max }\left(\mathrm{cm}^{-1}\right) 1742(2 \times \mathrm{C}=\mathrm{O}$, ester $), 1600(2 \times \mathrm{C}=\mathrm{N}), 1523\left(2 \times \mathrm{NO}_{2}\right.$, ester $), 1347(2 \times$ $\mathrm{NO}_{2}$, ester). ${ }^{1} \mathrm{HNMR}$ (DMSO-d6, $\left.400 \mathrm{MHz}\right) \delta 8.35-8.31(2 \mathrm{H}, \mathrm{m}, 2 \times \mathrm{Ar}-\mathrm{CH}), 8.21(4 \mathrm{H}, \mathrm{d}, J 8.2,4 \times \mathrm{Ar}-\mathrm{CH}), 8.13$ - $8.09(2 \mathrm{H}, \mathrm{m}, 2 \times \mathrm{Ar}-\mathrm{CH}), 7.90(4 \mathrm{H}, \mathrm{d}, J 7.9,4 \times \mathrm{Ar}-\mathrm{CH}), 2.20\left(6 \mathrm{H}, \mathrm{s}, 2 \times \mathrm{CH}_{3}\right)$. Mass spec m/z $\left(\mathrm{C}_{24} \mathrm{H}_{18} \mathrm{~N}_{4} \mathrm{O}_{8}, \mathrm{MWt}\right.$ 490.11) 490 (40), 467 (35), 453 (38), 425 (39), 394 (38), 368 (95), 353 (43), 163 (39), 149 (54), 103 (45), 83 (100), $65(50)$.

\section{Results and Discussion}

\subsection{Synthesis of Acetophenone Oximes 1 - 5}

A mixture of acetophenone derivative and solution of hydroxylamine hydrochloride in the presence of potassium hydroxide was refluxed for 30 to $45 \mathrm{~min}$. The corresponding acetophenone oximes were obtained as solid materials in moderate to good yields (Scheme 1).

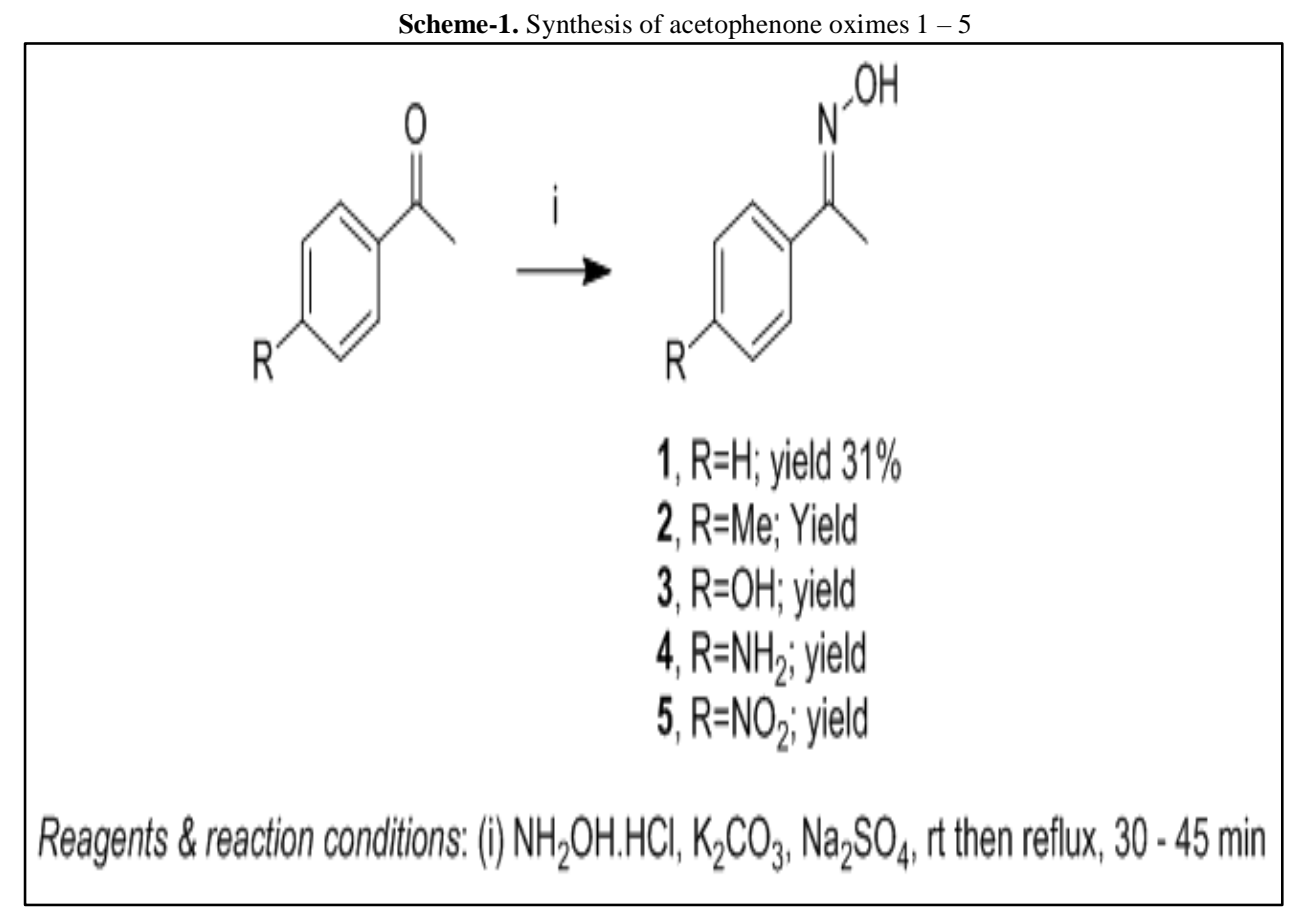

The spectroscopic analysis for the resulting compounds revealed the formation of the acetophenone oximes $\mathbf{1}-$ 5. The IR data showed the absorption of the $(\mathrm{OH})$ and the $(\mathrm{C}=\mathrm{N})$ groups at the expense of the carbonyl group $(\mathrm{C}=\mathrm{O})$ of the acetophenone derivative. The mass spectrometer gave the expected molecular ion masses along with the fragmentation patterns for all acetophenone oximes $\mathbf{1}$ - 5. The ${ }^{1} \mathrm{HNMR}$ also confirmed the formation of all oximes 1 - 5. Except the acetophenone oxime 1, which was obtained in two isomeric forms $E / Z$ in ratio of about (8:1), the other acetophenone oximes $\mathbf{2} \mathbf{- 5}$ were obtained as single isomers (Fig 1) [12].

Figure-1. The two isomers $(E / Z)$ of the acetophenone oxime 1<smiles>C/C(=N\O)c1ccccc1</smiles>

major E-isomer<smiles>C/C(=N/O)c1ccccc1</smiles>

minor Z-isomer 


\subsection{Synthesis of the Bridged Terphthaloyl Acetophenone Oxime Esters 6 - 10}

The synthesis of the oxime esters $\mathbf{6}-\mathbf{1 0}$ was carried out through a $n$ esterification reaction between the acetophenone oxime derivative and terphthaloyl chloride in the ratio of $(2: 1 \mathrm{~mole} / \mathrm{mole})$ under mild basic conditions at $0{ }^{\circ} \mathrm{C}$ to room temperature. The desired terphthaloyl oxime esters $\mathbf{6}-\mathbf{1 0}$ were formed in moderate yields as solid materials (Scheme 2).

Scheme-2. Synthesis of oxime esters $6-10$

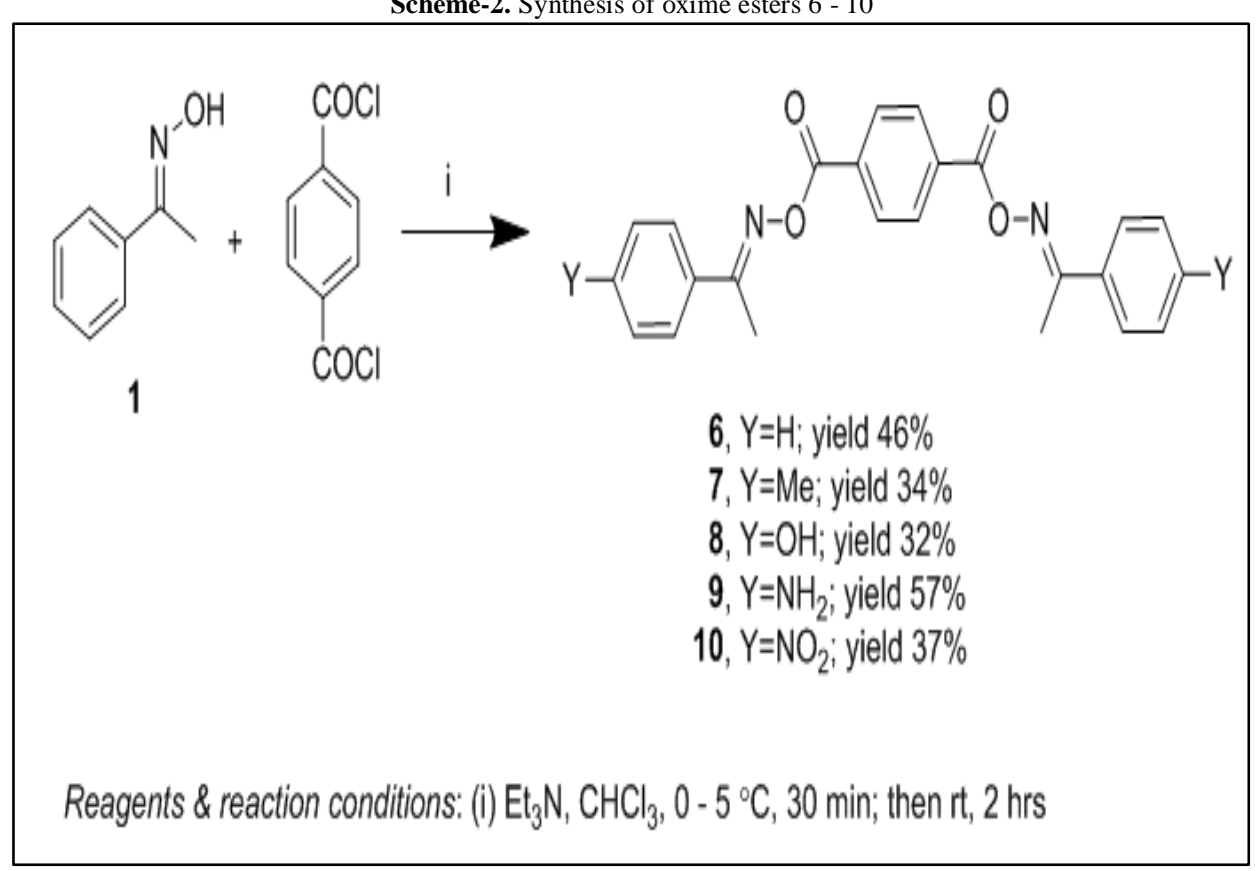

The IR spectroscopic data revealed the disappearance of the oxime hydroxyl group and the formation of the ester groups (COO) as strong absorption bands for the entire oxime esters $\mathbf{6}-\mathbf{1 0}$. The ${ }^{1} \mathrm{HNMR}$ data of the oxime ester $\mathbf{6}$ confirmed the formation of these esters as all expected chemical shifts for all different protons appeared on the spectrum and the disappearance of the oxime hydroxyl proton of the starting oximes. The mass spectrometer provided additional evidence on the formation of the oxime esters $\mathbf{6}-\mathbf{1 0}$. The molecular ion masses were observed at $400,428,432,430$ and $490 \mathrm{~m} / \mathrm{z}$ along with other molecular fragments for the oxime esters $\mathbf{6}-\mathbf{1 0}$ respectively, which were in a line with the expected theoretical fragmentation patterns.

The oxime 1 showed an excellent inhibitory level against the A. niger reaching 100\%. However, its corresponding terphthaloyl ester $\mathbf{6}$ showed the lowest inhibitory level of all oxime derivatives under study, which was found to be $38 \%$. The 4-methylacetophenone oxime 2 and its corresponding terphthaloyl ester 7, however, showed totally different results, recording $64 \%$ and $100 \%$ of inhibitory level respectively (Table 1). The 4hydroxyacetophenone oxime $\mathbf{3}$ and its corresponding ester $\mathbf{8}$ followed similar behavior to that was recorded for the oxime 1 and the acetophenone terephthaloyl ester $\mathbf{6}$ (Table 1).

Table-1. The inhibitory levels of the acetophenone oxime derivatives $1-10$ at concentration of (30 ppm) against A. niger using two commercially available antifungal agents clorotimazole and daktarin as references. Note that the two references showed inhibitory levels matching $\sim 63 \%$ and $68 \%$ respectively

\begin{tabular}{l|l}
\hline Oxime derivative & Inhibitory level (\%) \\
\hline 1 & 100 \\
\hline 2 & 64 \\
\hline 3 & 100 \\
\hline 4 & 69 \\
\hline 5 & 72 \\
\hline 6 & 38 \\
\hline 7 & 100 \\
\hline 8 & 66 \\
\hline 10 & 59 \\
\hline
\end{tabular}

The inhibition level for the oxime $\mathbf{3}$ reached 100\%, whereas its corresponding oxime ester $\mathbf{8}$ showed just about $66 \%$ of inhibition. The 4-aminoacetophenone oxime 4 exhibited rather good inhibition level recording about $69 \%$. The terephthaloyl ester 9 of the oxime 4 showed only 10\% drop in the inhibition level (59\%) in compassion with its oxime 4 (Table 1). The oxime, 4-nitroacetophenone 5, showed rather very good level of inhibition against the $A$. niger matching $72 \%$ of inhibition level. Interestingly, its corresponding terphthaloyl ester $\mathbf{1 0}$ showed exactly the same level of inhibition (72\%) (Table 1). 
Most of the oxime derivatives being synthesized throughout this study showed inhibitory levels better than the two references. Three of the synthesized oxime derivatives showed excellent levels of inhibition reaching $100 \%$. Such high level of inhibition never allowed the A. niger to grow (Fig. 2).

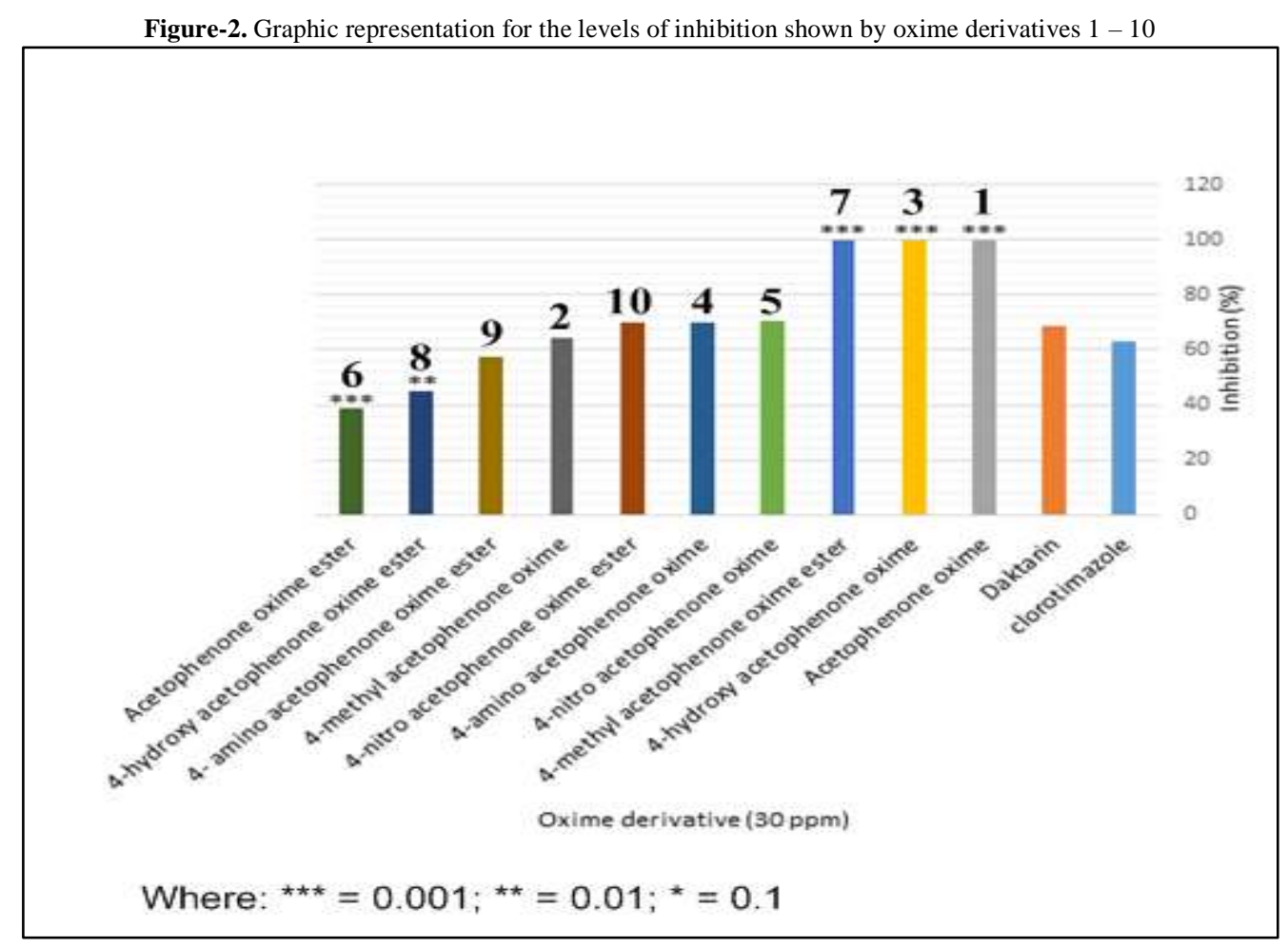

\section{Conclusion}

Acetophenone oximes $\mathbf{1}-\mathbf{5}$ along with their terphthaloyl oxime esters $\mathbf{6}-\mathbf{1 0}$ have been synthesized in moderate to good yields. Only the acetophenone oxime $\mathbf{1}$ was formed in a mixture of $E / Z$ isomers in a ratio of (8:1). The antimicrobial properties of these oxime derivatives were investigated against the Aspergillus niger at a concentration of $30 \mathrm{ppm}$. The commercially available antifungal agents, clorotimazole and daktarin, were used as references. The obtained results of the antifungal study for the oxime derivatives $\mathbf{1}-\mathbf{1 0}$ showed levels of inhibition ranging from $38 \%$ to $100 \%$, whereas the antifungal effects for the two references were found to be $\sim 63 \%$ and $68 \%$ for clorotimazole and daktarin respectively. Two oximes $\mathbf{1}$ and $\mathbf{3}$ along with the 4-methylacetophenone ester $\mathbf{7}$ showed the maximum levels of inhibition matching 100\% inhibition. However, the oxime ester $\mathbf{6}$ showed the lowest inhibitory level (38\%). Generally, the oximes showed higher inhibitory levels than those recorded for either their corresponding terphthaloyl esters and the commercially available two antifungal agents, clorotimazole and daktarin.

\section{Acknowledgements}

Authors would like to thank the Bioresearch Center, Department of Chemistry/Faculty of Science at the Misurata University for supporting this work and providing all required facilities to this research project.

\section{References}

[1] Bawa and Sawalem, M., 2018. "Synthesis and spectroscopic study of acetyl acetone mono oxime and its corresponding benzoyl ester." Int. Journal of Academic Research, vol. 12, p. 346-55.

[2] Vessally, E., Saeidian, H., Hosseinian, A., Edjlali, L., and Bekhradnia, A., 2017. "A review on synthetic applications of oxime esters." Current Organic Chemistry, vol. 21, pp. 249-71.

[3] Hwu, J. R., Tsay, S. C., Hong, S. C., Hsu, M. H., Liu, C. F., and Chou, S. S. P., 2013. "Relationship between structure of conjugated oxime esters and their ability to cleave DNA." Bioconjugate Chem, vol. 24, pp. $1778-83$.

[4] Crichlow, G. V., Cheng, K. F., Dabideen, D., Ochani, M., Aljabari, B., Pavlov, V. A., Miller, E. J., Lolis, E., and Al-Abed, Y., 2007. "Alternative chemical modifications reverse the binding orientation of a pharmacophore scaffold in the active site of macrophage migration inhibitory factor." Journal of Biological Chemistry, vol. 282, pp. $23089-95$.

[5] Enders, D., Grossmann, A., and Van, C. D., 2013. "N-Heterocyclic carbene catalyzed synthesis of oxime esters." Organic and Biomolecular Chemistry, vol. 11, pp. 138 - 41.

[6] Hayashi, I. and Shimizu, K., 1983. "Reactivity of aromatic o-hydroxy oximes II. The use of esters of aromatic o-hydroxy oximes in peptide synthesis." Bulletin of the Chemical Society of Japan, vol. 56, pp. 3197-98. 
[7] Bachovchin, D. A., Wolfe, M. R., Masuda, K., Brown, S. J., Spicer, T. P., Fernandez-Vega, V., Chase, P., Hodder, P. S., and Rosen, H., 2010. "Oxime esters as selective, Covalent inhibitors of the serine hydrolase retinoblastoma-binding protein 9 RBBP9." Bioorg Med Chem Lett., vol. 20, pp. 2254-58.

[8] Bindu, P., Mahadevan, K., Satyanarayan, N., and Naik, T. R., 2012. "Synthesis and DNA cleavage studies of novel quinoline oxime esters." Bioorganic and Medicinal Chemistry Letters, vol. 22, pp. 898 - 900.

[9] Bawa and Sawalem, A. M., 2018. "Synthesis of some unsymmetrical dioxime esters using the acetylacetone as a precursor." Scientific Review, vol. 5, pp. 19-23.

[10] Parthiban, P., Balasubramanian, S., Aridoss, G., and Senthamaraikannan, K., 2005. "Synthesis and microbiological evaluation of some n-methyl piperidone oxime ethers." Medicinal Chemistry Research, vol. 14, pp. 523-38.

[11] Balogia, A., Kovendi, A., Rotart, L., and Craciaescu, E., 1964. "Method of preparing p-ntroaceto phenone and its oxime."

[12] Bawa and Friwan, M., 2019. "Synthesis of acetophenone oxime and determination of the ration of its geometric isomers." In The Third Conference on Theories and Applications of Basic and Biosciences, 7 September, 2019, Faculty of Science, Misurata University, Misurata, Libya. 